\title{
COMPARISON OF TREMOR RELATED ADVERSE DRUG REACTION BETWEEN INTRAVENOUS AMINOPHYLLINE AND NEBULIZED SALBUTAMOL FOR ASTHMA EXACERBATION TREATMENT
}

\author{
Amelia Lorensia*, Nur Annisa Yuliana \\ Faculty of Pharmacy, University of Surabaya \\ *:amelia.lorensia@gmail.com; amelia.lorensia@staff.ubaya.ac.id
}

\begin{abstract}
The Department of Health estimates that asthma including 10 major causes of morbidity and mortality in the hospital. Asthma is a chronic respiratory disease that is becoming a serious health problem in many countries around the world. Drugs used in the treatment of asthma exacerbations is salbutamol and aminophylline. Drugs such as salbutamol and aminophylline can cause ADR (Adverse Drug Reaction) in the form of tremor with a sign involuntary shaking part of the hand. This research was conducted at the RSAL Dr. Oepomo to sample Aminofilin and in hospitals Seowandi to sample Salbutamol. The method used was quasi experimental. This study was conducted to compare the incidence of tremor in both asthma drug that is often used for the treatment of asthma such as Salbutamol and Aminofilin. The results of this study indicate there are differences in the incidence rate of ADR-related tremor between salbutamol and Aminofilin. Knowing the difference in incidence rate of tremor between aminophylline and salbutamol can assist in the selection of treatment which safer to avoid the effects of tremors that can occur from the use of of drugs asthma exacerbations.
\end{abstract}

Keywords: ADR (Advrese Drug Reaction), The incidence rate of Tremor, Intravenous Aminophylline, Salbutamol Nebulized, Asthma Exacerbation

\begin{abstract}
ABSTRAK
Departemen Kesehatan memperkirakan bahwa asma termasuk 10 penyebab utama morbiditas dan mortalitas di rumah sakit. Asma adalah penyakit pernafasan kronis yang menjadi masalah kesehatan yang serius di banyak negara di dunia. Obat yang digunakan dalam pengobatan eksaserbasi asma adalah salbutamol dan aminofilin. Obat-obatan seperti salbutamol dan aminophylline dapat menyebabkan ADR (Adverse Drug Reaction) berupa tremor dengan tanda bagian tangan yang tidak disengaja. Penelitian ini dilakukan di RSAL Dr. Oepomo untuk pengambilan sampel Aminofilin dan di RSUD Seowandi untuk pengambilan sampel Salbutamol. Metode yang digunakan adalah eksperimen semu. Penelitian ini dilakukan untuk membandingkan kejadian tremor pada kedua obat asma yang sering digunakan untuk pengobatan asma seperti Salbutamol dan Aminophylline. Hasil penelitian ini menunjukkan ada perbedaan angka kejadian tremor terkait ADR antara salbutamol dan Aminofilin. Mengetahui perbedaan laju kejadian tremor antara aminofilin dan salbutamol dapat membantu dalam pemilihan pengobatan mana yang lebih aman untuk menghindari efek tremor yang dapat terjadi akibat penggunaan obat eksaserbasi asma.
\end{abstract}


Kata kunci: ADR (Advrese Drug Reaction), Tingkat kejadian Tremor, Intravenous Aminophylline, Salbutamol Nebulized, Asma Eksaserbasi

\section{INTRODUCTION}

Asthma is a heterogeneous disease and is characterized by chronic inflammatory disorders of the airways with classifications such as wheezing, breathless, chest of thighness, coughing and airflow limitation. ${ }^{1}$ Based on WHO data, the world population suffering from asthma is estimated at 235 million. More than $80 \%$ of deaths caused by asthma occur in populations with lower socioeconomic levels. ${ }^{2}$ In Indonesia the prevalence of asthma is not known with certainty, but it is estimated that $2-5 \%$ of Indonesia's population suffers from asthma. The Ministry of Health estimates that asthma is among the top 10 causes of illness and death in hospitals and an estimated $10 \%$ of Indonesia's 25 million people suffer from asthma. ${ }^{3}$

Asthma exacerbation is a worsening and dangerous lifethreatening episode of asthma, so it requires best management treatment. ${ }^{1,4}$ Salbutamol is the SABA (short-acting beta2 agonist) group that is most widely used or prescribed for the treatment of asthma exacerbation, ${ }^{\mathbf{1 , 5}}$ SABA can relax bronchial smooth muscle by stimulating $\beta 2$ receptors in the respiratory tract, skeletal muscles and the heart so that due to crossactivation of $\beta_{1}$ ARS, with activation of these leading to tremor. ${ }^{6,7}$ But in addition to beta-agonist drugs (salbutamol), other classes of drugs such as methyxanthine also have the risk of side effects of tremors. ${ }^{\mathbf{8 9}}$ Medication to deal with asthma therapy can be given several asthma medications including methylxanthines such as theophylline and aminophylline. Aminophylline is a compound in the form of theophylline salt which has the effect of stimulating $\beta 2$ receptors which will cause bronchial muscle relaxation thereby reducing bronchospasm. ${ }^{\mathbf{1 0}}$ Aminophillin is a drug with a narrow therapeutic index so that even a slight change in plasma drug levels can cause toxic events. If the administration of aminophillin doses is not given carefully, adverse effects can occur, including ADR (adverse 
drug reactions), so it is necessary to observe the emergence of side effects of drugs in the use of aminofillin for asthma patients, but in Indonesia there are still many who get treatment with aminophylline. In Indonesia, aminophylline is one of the methylxanthene groups still often used in the treatment of asthma exacerbations. ${ }^{11,12,13}$ Drugs such as salbutamol and aminophylline can cause tremors with a vibrating sign of part of the hand. Trembling occurs when you want to hold hands, hold hands or head in various positions. ${ }^{\mathbf{1 4}}$ The exact mechanism for induction of tremor by $\beta 2$-adrenergic agonists is still unknown, but there is some evidence that $\beta 2$-adrenergic agonists act directly on muscles that cause tremors that occur solely because of direct stimulation of skeletal muscle by $\beta 2$-adrenoceptors. ${ }^{15}$

Adverse drug reaction (ADR) due to drugs very often occur every day in various treatment measures. ADR is interpreted as a dangerous and undesirable effect of drug administration at standard doses and with the right route aimed at prophylaxis, diagnosis and treatment.
Some drug reactions can occur in every human while others only occur in vulnerable patients. ADR reactions to drugs in asthma patients occur in medical action, which indicates that some drugs can cause ADR in asthma patients. ${ }^{16}$ The reason for the comparison of nebulized salbutamol and intravenous aminophylline for is because the hospital that conducted the study requested treatment of asthma exacerbations using nebulized salbutamol as well as in hospitals for aminophylline. The two hospitals where the researchers conducted the research wanted that the preparations used at the hospital were in accordance with the wishes of the hospital. The danger of tremor occurrence in this case is related to effects on the central nervous system. Although the use of drugs in this case are asthma exacerbation drugs such as salbutamol and aminophylline only used if the exacerbation of asthma appears, but if the exacerbation condition continues and the use of salbutamol and aminophylline are known to have side effects on the $\mathrm{CNS}$, it can cause a tremor effect that can interfere with the patient's 
condition after the asthma exacerbation the patient has experienced. Irregular tremor conditions can cause severe functional disability. ${ }^{17}$ This study was conducted to determine differences in the incidence rate of tremor related to ADR for asthma patients who received nebulized salbutamol agonist and intravenous aminophylline therapy.

\section{METHOD}

\section{Design of research}

This type of research is quasiexperimental. Subjects would be divided into 2 groups, was nebulized salbutamol and intravenous aminophylline therapy.

\section{Research variable}

The independent variables in this study were the drugs used for exacerbation of asthma, namely nebulized salbutamol and intravenous aminophylline groups. The dependent variable in this study is ADR related to tremor. The drugs used for asthma exacerbation therapy in this study were:

1. Nebulized salbutamol. In this study salbutamol was used with a nebulation preparation at a dose of $2 \times 5 \mathrm{mg}$ or $2 \mathrm{ml}$ of $0.5 \%(+2 \mathrm{ml}$ saline). ${ }^{18}$

2. Intravenous aminophylline. In this study I used aminophylline i.v, administered slowly with a loading dose of $6 \mathrm{mg} / \mathrm{kg} / \mathrm{hour}$ for 20 minutes then followed by maintenance doses with an infusion $(\mathrm{NaCl} \quad 0.9 \%)$ of 5 $\mathrm{mcg} / \mathrm{kg} /$ hour. Theophylline $1 \mathrm{mg}$ is equivalent to $1.25 \mathrm{mg}$ of aminophylline. .,19,20 $^{2}$

Tremors were the most common neurological conditions. A tremor was also an unintentional movement of the vibrating rhythm of each part of the body. The body parts most commonly affected were the hands, but can also occur in other parts such as the head, voice and feet. Tremors were side effect of beta-adrenoceptor and methyl xanthine agonist groups. ${ }^{10}$ Tremor frequency can be estimated based on observations with the naked eye and was more accurately measured with surface electromyography, accelerometry. The clinical appearance of this syndrome was often sufficient to be characterized as an accurate diagnosis 
without measuring the frequency of tremors. $^{21}$

\section{RESULT AND DISCUSSION}

The population in this study amounted to 105 patients who came to the IGD Hospital Dr. Soewandhi and RSAL Dr. Oepomo Surabaya with a sample of patients who were willing to participate in the study as many as 57 patients who met the inclusion criteria and were divided into two groups. Of the total population in this study, the number of patients who refused to participate in the study were 21 patients and those who met the exclusion criteria were 27 people. The profile of the characteristics of research subjects could be seen in Table $\mathbf{1}$.

Tremor events based on the observation time of the two groups can be seen in table 2. Although some respondents did not experience tremors, there were $22.22 \%$ tremors in nebulized salbutamol group and $20 \%$ in intrevenous aminophylline group. The assessment of tremor events can be seen in Table 3, where tremors occurred after being given therapy and there were no such symptoms (possible ADR event) in $14.81 \%$ of the nebulized salbutamol group and $10.00 \%$ in the intravenous aminophylline group.

\section{Table 1. Profile of Research Subject Characteristics}

\begin{tabular}{llcccc}
\hline & & \multicolumn{2}{c}{$\begin{array}{c}\text { Nebulized salbutamol Group } \\
\text { (n:30) }\end{array}$} & \multicolumn{2}{c}{$\begin{array}{c}\text { Intravenous aminophylline } \\
\text { Group (n:27) }\end{array}$} \\
\cline { 3 - 6 } & & Frequency & Percentage (\%) & Frequency & Percentage (\%) \\
\hline Gender & Female & 19 & 63.33 & 14 & 51.85 \\
& Male & 11 & 36.67 & 13 & 48.15 \\
\hline Age & $18-25$ & 7 & 23.33 & 5 & 18.52 \\
Years) & $26-35$ & 5 & 16.67 & 5 & 18.52 \\
& $36-45$ & 4 & 13.33 & 7 & 25.93 \\
& $46-55$ & 7 & 23.33 & 8 & 29.63 \\
& 56-65 & 6 & 20.00 & 2 & 7.41 \\
& $>65$ & 1 & 3.33 & 0 & 0.0 \\
\hline Employee & Private employees & 2 & 6.67 & 3 & 11.11 \\
& Entrepreneur & 13 & 36.67 & 10 & 37.04 \\
& Housewife & 9 & 30.00 & 10 & 37.04 \\
& Unemployee & 2 & 6.67 & 0 & 0 \\
& Student & 4 & 13.33 & 4 & 0 \\
\hline Disease & No comorbidities & 25 & 83.33 & 27 & 100.00 \\
History & Hypertension + Gout & 1 & 3.33 & 0 & 0.00 \\
& Gastritis & 1 & 3.33 & 0 & 0.00 \\
& Hypertension & 1 & 3.33 & 0 & 0.00 \\
& Type 2 Diabetes Mellitus & 1 & 3.33 & 0 & 0.00 \\
& Hypertension + Gastritis + & 1 & 3.33 & 0 & 0.00
\end{tabular}


Table 2. Time of Observation from Tremor Event

\begin{tabular}{llcccc}
\hline & & \multicolumn{2}{c}{$\begin{array}{c}\text { Nebulized salbutamol Group } \\
(\mathbf{n : 3 0 )}\end{array}$} & \multicolumn{2}{c}{$\begin{array}{c}\text { Intravenous aminophylline } \\
\text { Group (n:27) }\end{array}$} \\
\hline \multirow{2}{*}{ Time Observation } & \multicolumn{1}{c}{ Tremor event } & Frequency & Percentage (\%) & Frequency & Percentage (\%) \\
\hline \multirow{2}{*}{ t0 } & Tremor & 2 & 7.40 & 7 & 23.33 \\
\cline { 2 - 6 } & No tremor & 25 & 92.60 & 23 & 76.76 .67 \\
\cline { 2 - 6 } & TOTAL & 27 & 100 & 30 & 100 \\
\hline \multirow{2}{*}{1} & Tremor & 6 & 22,22 & 6 & 20.00 \\
\cline { 2 - 6 } & Tidak tremor & 21 & 77,78 & 24 & 80.00 \\
\cline { 2 - 6 } & TOTAL & $\mathbf{2 7}$ & $\mathbf{1 0 0}$ & $\mathbf{3 0}$ & $\mathbf{1 0 0}$ \\
\hline
\end{tabular}

t0 : before being given nebulized salbutamol or intravenous aminophylline therapy

t1 : 1 hour after being given nebulized salbutamol or intravenous aminophylline therapy

Table 3. Assessment of Changes in Tremor Occurrence Before and After Therapy

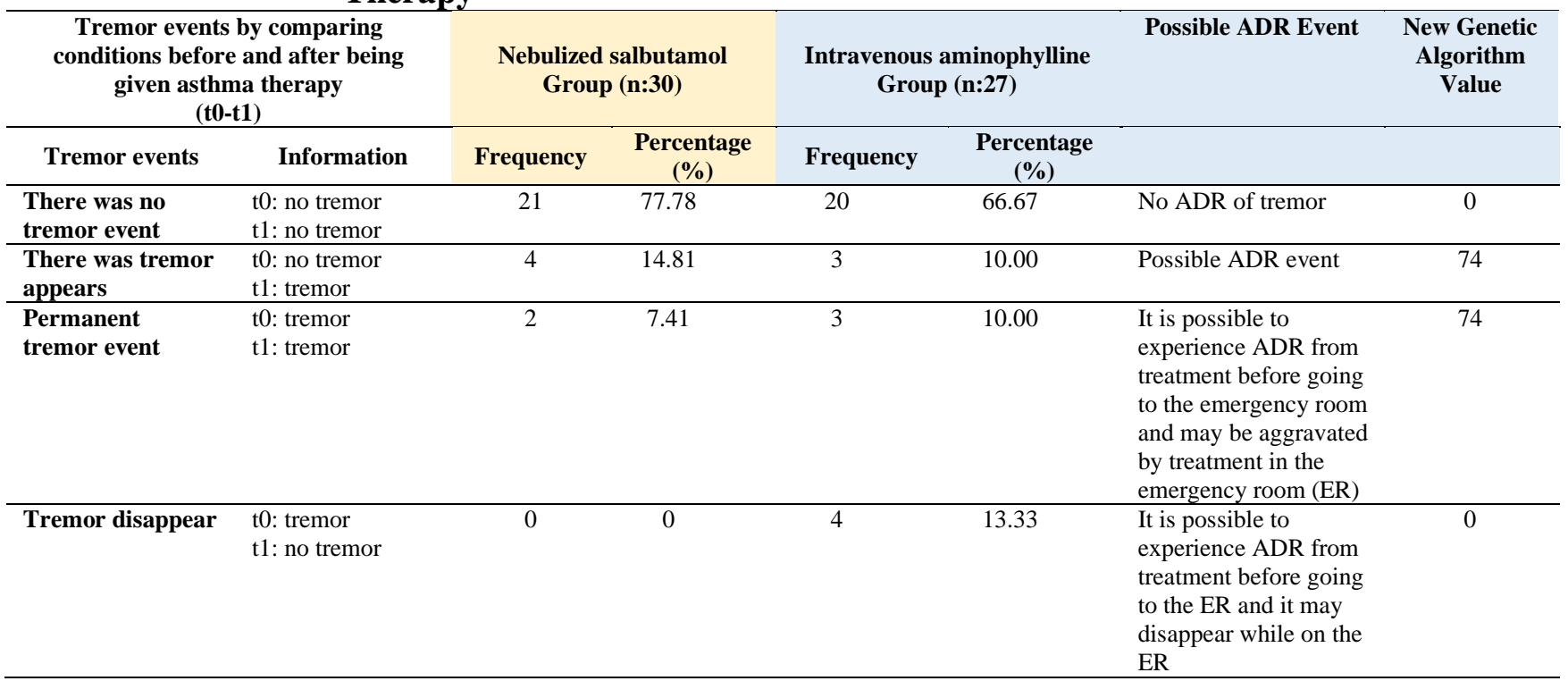

t0 : before being given nebulized salbutamol or intravenous aminophylline therapy

t1 : 1 hour after being given nebulized salbutamol or intravenous aminophylline therapy

Adenosine is the main modulator for neuron activity and the release of neurotransmitters in the central nervous system, by inhibiting transmitter release of $\mathrm{A} 1$ receptors and $\mathrm{A} 2$ receptors, which generally if the release of some of these transmitter systems is related to control in movement. Adenosine antagonists, such as theophylline have been reported to increase tremors in cases of Parkinson's disease and essential tremor $(22,23)$. The effect on calcium is proof that methylxanthines can facilitate the release of calcium from the endoplasmic reticulum in skeletal and cardiac muscles. Methylxanthines can affect the 
transport of calcium across cell membranes. Considering the very important role of calcium in muscle contraction and the process of release in calcium can explain certain actions in methylxanthine (24). Tremor is one of the most characteristic adverse effects following administration of $\beta(2)$-adrenergic agonists. It is reported by around $2-4 \%$ of patients with asthma taking a regular $\beta(2)$ adrenergic agonist and is induced by both short-acting and long-acting agents (15).

The prevalence of theophylline is not known with certainty. The exact mechanism of theophylline-induced tremors is largely unknown, but is likely a result of enhancement of physiological tremor. It is known that theophylline has the ability to mobilize intracellular calcium, antagonize adenosine receptors, and also may produce a slight rise in catecholamine levels in the central nervous system (25).

The assessment of tremor events in this study was carried out by observing the patient's condition before and after being given intravenous salbutamol therapy and intravenous aminophylline.

Observation of tremor events was seen in the patient's body parts especially the hands. In a seated state, the patient will observe whether or not his hand shakes before and after therapy. If the patient's hand vibrates, tremors can be said. The most common method for evaluating tremors electronically was accelerometry, which uses sensors to measure the acceleration of body parts. Accelerometers are the main tools for the identification of tremors, measuring the strength of linear acceleration in three orthogonal directions, capable of capturing the movements of limbs produced by gravitational action and muscle action, including tremor (26). Assessment of tremor events is also usually done by physical observation, conducting tests in terms of seeing the ability of the functions of talking, drinking, eating, doing activities such as holding an item, asking patients to draw a shape for example a spiral shape on paper and then compared to its normal form (27). The assessment of tremor events in this study was carried out only by physical 
observation and was not carried out with various conditions such as having the patient do some activities because exacerbation patients were not possible to do so. The assessment of tremor in this study may not be sufficient to say ideal because the assessment of tremor is more ideal if it uses physical observation, checks using image patterns and uses tools to measure tremors such as accelerometry that can measure the frequency and amplitude of changes in movement that cannot be seen by the eye.

The limitation in this study was that in the ADR assessment using the New Genetic Algorithm some questions cannot be assessed and answered because there was no known data information or because the process is not done. The question in question is:

a. What are undesirable reactions due to existing clinical conditions?

b. When the drug is stopped does the unwanted reaction improve within a reasonable period of time? c. When the drug is NOT stopped, does the reaction go away on its own?

d. Does the reaction improve when given a specific antagonist / antidote for the drug?

e. Do unwanted reactions reappear when the suspected drug is stopped and given back?

This research was only carried out when the patient was in the hospital emergency room, the patient was given therapy for one hour so that the time was quite limited and when the patient had received therapy, so some things could not be done and the patient's data was not completely known. In this study the assessment of tremor was only carried out by physical observation and the condition that was known as a trigger factor for tremor in this case the psychological condition of the patient such as anxiety, stress and depression that could not be known, while the condition was likely to affect the results of the tremor assessment.

\section{CONCLUSION}

Assessment through the ChiSquare statistical test in this study 
showed that there were differences in the incidence of tremor related to ADR (adverse drug reaction) between the nebulized salbutamol and intravenous aminophylline groups. Probability assessment using the New Genetic Algorithm for ADR-related tremor events in this study gave results, namely, from the intravenous aminophylline group with a total of 4 patients who experienced tremors in which 3 patients were in the possible ADR category (1) and 1 patient was in the definite ADR category. (definitely) and in the salbutamol group with a total of 3 patients who experienced tremors in which all three patients were included in the possible ADR (probable) category. The results of the assessment indicate that the tremors that occur are likely ADRs caused by the use of intravenous aminophylline and salbutamol nebulation in asthma exacerbation patients.

\section{CONFLICT OF INTEREST}

The authors declare that they have no conflicts of interest.

\section{REFERENSI}

1. Global Initiative for Asthma, 2017, Global Strategy For Asthma Management And Prevention

2. Word Health Organization. $2017 . \quad$ Asthma. https://www.who.int/newsroom/factsheets/detail/asthma

3. Oemiati $\mathrm{R}$, Sihombing $\mathrm{M}$, Qomariah, 2010, Faktor-Faktor yang berhubungan dengan Penyakit Asma di Indonesia, Media Litbang Kesehatan, 20(1),41-9.

4. Camargo CA, Rachelefsky G, Schatz M, 2009, Managing asthma exacerbations in the emergency department: Summary of the National Asthma Education and Prevention Program Expert Panel Report 3 guidelines for the management of asthma exacerbations, $J$ Allergy Clin Immunol, 124(2),S5-14.

5. Chin MC, Sivasampu S, Khoo EM, 2017, Prescription of oral short-acting beta 2 -agonist for asthma in non-resource poor settings: A national study in Malaysia, PLoS One, 12(6),e0180443.

6. Asthma Management Handbook, 2006, National Asthma Council Australia

7. Billington $\mathrm{CK}$, Penn RB, Hall IP, 2017, $\beta_{2}$ Agonists, Handb Exp Pharmacol., 237:23-40.

8. Schoen K, Yu T, Stockmann C, Spigarelli MG, Sherwin CM, 2014, Use of methylxanthine therapies for the treatment and prevention of apnea of prematurity, Paediatr Drugs, 16(2),169-177. 
9. Buss DC, Marshall RW, Milligan N, McQueen I, Compston DAS, Routledge PA, 1997, The effect of intravenous aminophylline on essential tremor, $\mathrm{Br}$ Clin Phormocol, 43,I19-21.

10. Essential Tremor Patient Handbook, 2013, International Essential Tremor Foundation.

11. Lorensia A, Wahjuningsih E, Canggih B, Lisiska N, 2011, Pharmacist's Strategies in Treating Asthma Bronchiale Outpatient, Jurnal of Tropical Pharmacy and Chemistry, 1(3), 177-91.

12. Lorensia A, Wahjuningsih E, Supriadi, 2012, Safety of Aminophylline for Asthma Therapy in Delta Surya Hospital at Sidoarjo, Indonesia journal of Clinical Pharmacy, 1(4),154-61.

13. Lorensia A, Amalia RA, 2015, Pharmacovigilance Study of Asthma Treatment in Inpatient Patients at a Hospital in Bojonegoro, Jurnal Ilmiah Manuntung, 1(1):8-18.

14. Demir S, Demir AU, Oztuna D, Kalyoncu AF, 2015, Frequency and Factors of Tremor, Palpitation, and Cramp in Patients with COPD and Asthma, Eurasian $J$ Pulmonol, 17, 22-8.

15. Cazzola M, Matera MG, 2012, Tremor and $\beta(2)$-adrenergic agents: is it a real clinical problem?, Pulm Pharmacol Ther, 25(1),4-10.

16. Coleman JJ, Pontefract SK, 2016, Adverse drug reactions, Clin Med (Lond), 16(5),481-5.

17. Hedera P, Cibulčík F, Davis TL, 2013, Pharmacotherapy of essential tremor, $J$ Cent Nerv Syst Dis, 5,43-55.

18. Barnard A, 2005, Management of an Acute Asthma Attack, Australian Family Physician, 34(7),5314.

19. Fong $\mathrm{N}$, Aminophylline/theophylline: Loading and maintenance dose. NHS Trust: East Lancashire Hospitals; 2011.

20. Scottish Intercollegiate Guidelines Network, 2011, British Guideline on the Management of Asthma. British Thoracic Society, UK.

21. Puschmann A, Wszolek ZK, 2011, Diagnosis and Treatment of Common Forms of Tremor, General Approach to an Outpatient with Tremor, 31(1),65-77.

22. Sperlágh B, Vizi ES, 2011, The role of extracellular adenosine in chemical neurotransmission in the hippocampus and Basal Ganglia: pharmacological and clinical aspects, Curr Top Med Chem, 11(8),1034-46.

23. Mally J, Stone TW, 1996, Potential role of adenosine antagonist therapy in pathological tremor disorders, Pharmacol Ther, 72(3),24350.

24. Reddish FN, Miller CL, Gorkhali R, Yang JJ, 2017, Calcium Dynamics Mediated by the Endoplasmic/Sarcoplasmic 
Reticulum and Related Diseases, Int $\quad J \quad M o l \quad S c i$, 18(5), 1024.

25. Morgan JC, Kurek JA, Davis JL, Sethi KD, 2017, Insights into Pathophysiology from Medication-induced

Tremor, Tremor Other Hyperkinet Mov (NY), 7,442.

26. Andrade AO, Pereira AA, Soares MF, Cavalheiro GL, Paixão APS, Fenelon SB and
Dionisio VC, 2012, Human

Tremor: Origins, Detection and Quantification, Practical Applications in Biomedical Engineering, Chapter1, p4-17

27. Kovacs N, Pal E, Merkli H, Kellenyi L, Nagy F, Janszky J, Balas I, 2008, Bilateral effects of unilateral thalamic deep brain stimulation: a case report. Mov Disord,23(2),276-9. 